\title{
Forma aguda da doença enxerto contra o hospedeiro após transplante de fígado. Existe opção terapêutica para as formas refratárias ao tratamento com esteróides?
}

\author{
Acute graft versus host disease after liver transplantation. Do \\ we have an option for treatment of steroid-refractory forms?
}

\author{
Eleazar Chaib1, Brian Guilherme Monteiro Marta Coimbra², Felipe Duarte Silva², \\ Alexandre Fligelman Kanas², Eduardo Ryoiti Tatebe², Myris Satiko Shinzato², \\ Flavio Henrique Ferreira Galvão³, Luiz Augusto Carneiro D’Albuquerque ${ }^{4}$
}

Chaib E, Coimbra BGMM, Silva FD, Kanas AF, Tatebe ER, Shinzato MS, Galvão FHF, D'Albuquerque LAC. Forma aguda da doença enxerto contra o hospedeiro após transplante de fígado. Existe opção terapêutica para as formas refratárias ao tratamento com esteróides?/ Acute graft versus host disease after liver transplantation. Do we have an option for treatment of steroid-refractory forms? Rev Med (São Paulo). 2012 abr.-jun.;91(2):110-6.

ABSTRACT: Background: Acute graft-versus-host disease (GVHD) usually occurs by 8 weeks after liver transplantation (LT) usually is an uncommon complication but has both high mortality and major diagnostic challenge in addition most of them are associated with resistance to steroid therapy. Objective: Discuss the pathogenesis, treatment and long-term results of Acute Graft versus Host Disease after Liver Transplantation. Methods: A PubMed search was performed to identify all reported cases of GVHD following LT. The medical subject heading GVHD disease was used in combination with LT, including adults (19 + years) and children. The bibliographies of the articles found though PubMed were then searched for further reports of GVHD. Results: We reviewed 102 cases of acute GVHD, $96(94.1 \%)$ adults and $6(5.8 \%)$ children. After treatment $24(25 \%)$ adults and $3(50 \%)$ children were alive only. As far as the treatment of GVHD is concern the therapy used in adults and in children patients was respectively : anti-thymocyte globulin + prednisolone - 19 (19.5\%); interleukin-2 receptor blocker - 17 $(17.5 \%)$; OKT3 - $12(12.3 \%)$; cyclosporine $-9(9,2 \%)$; others $39(40.2 \%)$ and in children anti-thymocyte globulin - $1(20 \%)$; anti-thymocyte globulin + prednisolone $-1(20 \%)$; prednisolone $-1(20 \%)$; anti-thymocyte globulin + prednisolone + interleukin-2 receptor blocker-1 (20\%); not mentioned -1. There was no standard treatment of acute GVHD for both children and adults. Conclusion: Although acute GVHD following LT is rare complication and mortality is still very high, there is no consensus for the treatment of steroid-refractory forms. Further researches are needed to provide new approach for treating effectively such condition.

KEYWORDS: Liver transplantation; Graft vs host disease/etiology; Grafts vs host disease/therapy; Pathogenesis/treatment; Steroids/ therapeutic use.
RESUMO: Introdução: A forma aguda da doença do enxerto contra o hospedeiro ocorre geralmente até oito semanas após o transplante de fígado, é rara, porém tem mortalidade alta e constitui-se em um grande desafio terapêutico principalmente naqueles casos que são resistentes ao tratamento com corticóides. Objetivo: Discutir a patogênese, tratamento e resultados a longo prazo da Forma Aguda da Doença Enxerto contra o Hospedeiro após Transplante de Fígado. Métodos: Fizemos uma pesquisa na base de dados do PubMed procurando identificar todos os casos de doença Enxerto contra o Hospedeiro após Transplante de Fígado incluindo adultos com mais de 19 anos e crianças. Resultados: Revisamos 102 casos desta doença e encontramos $96(94,1 \%)$ adultos e 6 $(5,8 \%)$ crianças. Após o tratamento, $24(25 \%)$ adultos e $3(50 \%)$ crianças estavam vivos. Com relação ao tratamento da doença do enxerto contra o hospedeiro em adultos e crianças encontramos respectivamente: globulina anti-timocítica + prednisolona - 19 $(19,5 \%)$; bloqueador do receptor da interleucina $2-17(17,5 \%)$; OKT3 - $12(12,3 \%)$; ciclosporina - $9(9,2 \%)$; outros $-39(40,2 \%)$ e em crianças globulina anti-timocítica - $1(20 \%)$; globulina antitimocítica + prednisolona - $1(20 \%)$; prednisolona - $1(20 \%)$; globulina anti-timocítica + prednisolona + bloqueador do receptor da interleucina 2 -1 (20\%); não mencionado - 1. Conclusão: Pesquisas devem ser aprofundadas nos mecanismos que desencadeiam esta patologia. Não existe consenso para o tratamento da doença do enxerto contra o hospedeiro após o transplante de fígado naqueles doentes que são refratários ao uso de esteróides.

DESCRITORES: Transplante de fígado; Doença enxerto-hospedeiro/etiologia; Doença enxerto-hospedeiro/terapia; Patogênese/ tratamento; Esteróides/uso terapêutico.

\footnotetext{
1. Associate Professor of Surgery, Director Experimental Research Laboratory- LIM 37, Department of Gastroenterology, University of São Paulo School of Medicine, São Paulo, Brazil.

2. Medical Student, University of São Paulo School of Medicine, São Paulo, Brazil.

3. Assistant Professor of Surgery. LIM 37, Department of Gastroenterology, University of São Paulo School of Medicine, São Paulo, Brazil.

4. Professor of Transplantation Surgery, Department of Gastroenterology, University of São Paulo School of Medicine, São Paulo, Brazil.

Endereço para correspondência: E. Chaib, Liver Transplantation Unit and LIM-37, Department Gastroenterology University of São Paulo
} School of Medicine. Av. Dr. Arnaldo, 455 - 3rd floor, suite 3206, 01246-903, Sao Paulo, Brazil. e-mail: eleazarchaib@yahoo.co.uk 


\section{INTRODUCTION}

A cute graft-versus-host disease (GVHD) Ausually occurs by 8 weeks after liver transplantation (LT) ${ }^{1}$, and its prevalence has been estimated to be 0.3 to $1.9 \% 8,45,56,58$.

Acute GVHD following LT is an uncommon complication but has both high mortality and major diagnostic challenge and in addition to that most of them are associated with resistance to steroid therapy.

We reviewed 102 cases of acute GVHD in the past 23 years, discussing the pathogenesis, treatment and long-term results of this condition after LT.

\section{METHODS}

A PubMed search was performed to identify all reported cases of GVHD following LT. The medical subject heading GVHD disease was used in combination with $L T$, including adults (19+ years) and children. The bibliographies of the articles found though PubMed were then searched for further reports of GVHD.

The mean age of affected patients was 52 years in 96 adult patients and 5 years in 6 children. The onset of GVHD was similar in both groups, averaging approximately 1 month after LT for both adults and children. The clinical manifestations of GVHD were similar in both adult and children and consist of rash, fever, diarrhea and bone marrow involvement manifested by cytopenias.

\section{RESULTS}

We reviewed 102 cases of acute GVHD, 96 $(94.1 \%)$ adults and $6(5.8 \%)$ children. The primary difference seen between pediatric and adults patients was in mortality with $75 \%$ death rate in reported adult patients with GVHD vs. a $50 \%$ mortality rate for patients younger than 18 years. Of the 102 patients reported to have experienced of GVHD, only 27 were reported to be alive at the time of publication of their case (Table 1). 94 (92.15\%) patients demonstrating chimerism for confirming the diagnosis of GVHD after LT.

Table 1. Literature review. Acute graft vs host disease after liver transplantation. Treatment and results

\begin{tabular}{|c|c|c|c|c|c|c|}
\hline Reference & Patients & Basic IS & Onset & Chimerism & Therapy & Outcome \\
\hline Burdick et al. $(1988)^{5}$ & 1 & CsA,AZA,PSL & 21 & + & ATG, PSL & Alive \\
\hline Bhaduri et al. $(1990)^{3}$ & 1 child & AZA, PSL & 23 & + & ATG, PSL & Dead \\
\hline Marubayashi et al. $(1990)^{36}$ & 1 & CsA,AZA,PSL & 13 & + & ATG, PSL & Dead \\
\hline Merle et al. $(1990)^{39}$ & 1 & - & 30 & + & Anti-IL2R & Dead \\
\hline Jamieson et al. $(1991)^{25}$ & 2 & CsA,PSL,AZA,IL2-R blocker & $18 / 30$ & + & CsA, PSL, ATG & $1 \mathrm{x}$ dead \\
\hline Roberts et al. $(1991)^{64}$ & 4 & CsA,AZA,PSL & $18-42$ & ND & $3 x$ IS increase with PSL & $4 \mathrm{x}$ dead \\
\hline Comenzo et al. $(1992)^{13}$ & 1 child & CsA,PSL & 95 & + & IS increase & Alive \\
\hline Collins et al. $(1992)^{12}$ & 1 & CsA,AZA,PSL & 35 & + & PSL & Dead \\
\hline De Paoli et al. $(1992)^{15}$ & 1 & - & 14 & + & ATG, PSL & Dead \\
\hline Joysey et al. (1992) ${ }^{27}$ & 1 & - & 38 & + & ATG, PSL & Dead \\
\hline Mazzaferro et al. $(1993)^{37}$ & 1 & CsA,PSL & 17 & + & PSL & Dead \\
\hline Rosen et al. $(1993)^{51}$ & 1 & - & 24 & - & Anti L-AB & Dead \\
\hline Redondo et al. $(1993)^{49}$ & 1 & - & 25 & + & OKT3, PSL & Alive \\
\hline Neumann et al. $(1994)^{40}$ & 1 & CsA,AZA,PSL & 32 & + & ATG, OKT3 & Dead \\
\hline Cattral et al. $(1994)^{9}$ & 1 child & CsA,PSL & 16 & + & PSL & Alive \\
\hline Pageaux et al. $(1995)^{42}$ & 1 & CsA,AZA,PSL & 18 & + & ATG, PSL & Dead \\
\hline Connors et al. $(1996)^{14}$ & 1 & FK506,PSL & 24 & + & - & Dead \\
\hline Sanchez et al. $(1996)^{52}$ & 1 & CsA,AZA,PSL & 34 & + & OKT3 & Dead \\
\hline Whitington et al. $(1996)^{68}$ & 1 child & CsA,AZA,PSL & 34 & + & ATG & Alive \\
\hline Burt et al. $(1996)^{6}$ & 1 & - & 28 & + & PSL & Dead \\
\hline
\end{tabular}


Rev Med (São Paulo). 2012 abr.-jun.;91(2):110-6.

Table 1. Literature review. Acute graft vs host disease after liver transplantation. Treatment and results continuação

\begin{tabular}{|c|c|c|c|c|c|c|}
\hline Reference & Patients & Basic IS & Onset & Chimerism & Therapy & Outcome \\
\hline Kiuchi et al. $(1998)^{31}$ & 1 child & - & 27 & + & - & Dead \\
\hline Aziz et al. $(1998)^{2}$ & 1 & CsA,AZA,PSL & 15 & - & ATG & Alive \\
\hline Paizis et al. $(1998)^{41}$ & 1 & - & 21 & + & OKT3 & Alive \\
\hline Schmuth et al. $(1999)^{55}$ & 1 & FK506,PSL & 7 & + & AZA, PSL & Dead \\
\hline Joseph et al. $(1999)^{26}$ & 1 & CsA,AZA,PSL & 35 & + & CsA, Cyclophosphamide & Dead \\
\hline Merhav et al. $(1999)^{39}$ & 1 & FK506,PSL & 30 & + & CsA, PSL, ATG & Dead \\
\hline Hahn et al. $(2000)^{20}$ & 2 & CsA,PSL/ FK506,PSL & $35 / 21$ & + & OKT3 / Stop IS & Dead /Alive \\
\hline Au et al. $(2000)^{1}$ & 1 & FK506,PSL & 20 & + & AZA,PSL & Dead \\
\hline Hanaway et al. $(2001)^{21}$ & 1 & - & 18 & - & ATG,PSL & Dead \\
\hline Romognoulo et al. $(2000)^{50}$ & 1 & PLS, CsA & 23 & - & AZA,PSL & Dead \\
\hline Knox et al. $(2002)^{33}$ & 1 & FK506,MMF,PSL & 17 & + & PSL & Alive \\
\hline Lehner et al. (2002) $)^{34}$ & 1 & MMF, IL-2R & 21 & + & Stop IS & Alive \\
\hline Smith et al. $(2003)^{56}$ & 13 & FK506,AZA,PSL & 8-115 & + & IS increase PSL, GM-CSF & $12 x$ dead \\
\hline Sudhindran et al. $(2003)^{59}$ & 2 & FK506, PSL, AZA & $24 / 31$ & + & PSL, IL-2R Blocker & Alive / Dead \\
\hline Soejima et al $(2004)^{57}$ & 4 & CsA,PSL,FK506 & $27-114$ & + & $\begin{array}{l}\text { IS increase FK506, PSL, } \\
\text { CsA, ATG }\end{array}$ & 2x Dead \\
\hline Key et al. $(2004)^{30}$ & 7 & FK506,AZA,PSL & $14-56$ & + & $\begin{array}{l}\text { IS increase PSL, ATG, } \\
\text { IL-2R Blocker }\end{array}$ & $5 \times$ Dead \\
\hline Hara et al. $(2004)^{22}$ & 1 & CsA,PSL & 20 & + & $\begin{array}{l}\text { Change CsA to FK506, } \\
\text { ATG }\end{array}$ & Dead \\
\hline Walling et al. (2004) $)^{66}$ & 1 & FK506,PSL & 70 & + & MMF, PSL & Alive \\
\hline Pollack et al. $(2005)^{47}$ & 1 & FK506,MMF,PSL & 240 & + & OKT3, SCT & Dead \\
\hline Kamei et al. $(2006)^{28}$ & 8 & - & $14-114$ & - & - & 8x Dead \\
\hline Sun et al. $(2006)^{560}$ & 1 & FK506, MMF, PSL & 122 & + & PSL & Dead \\
\hline Schappi et al. $(2006)^{54}$ & 1 child & \begin{tabular}{|l|} 
MMF, FK506, PSL, IL2-R \\
Blocker
\end{tabular} & 1 & + & $\begin{array}{l}\text { IL-2R Blocker, } \\
\text { Alemtuzumab, ATG, PSL }\end{array}$ & Dead \\
\hline Ghali et al. $(2007)^{17}$ & 1 & \begin{tabular}{|l|} 
IL2-R Blocker, MMF, and PSL, \\
FK506
\end{tabular} & ND & + & $\begin{array}{l}\text { ATG, PSL, IL-2R Blocker, } \\
\text { G-CSF, Erythropoietin }\end{array}$ & Dead \\
\hline Chinnakotta et al. $(2007)^{10}$ & 3 & $\begin{array}{l}\text { 2x MMF, FK506, PSL / 1x } \\
\text { CsA, PSL, RAPA }\end{array}$ & $07-70$ & + & Stop IS & 2x Alive \\
\hline Perri et al. $(2007)^{45}$ & 5 & Standard IS & 23-35 & + & PSL, ATG and IL-2R & $5 x$ Dead \\
\hline Wang et al. $(2007)^{67}$ & 2 & FK506, PSL, MMF / CsA, PSL & $24 / 32$ & ND & PSL, GM-CSF & Dead /Alive \\
\hline Cho et al. $(2007)^{11}$ & 1 & FK506, PSL & 56 & + & IS increase & Dead \\
\hline Guo et al. $(2008)^{19}$ & 2 & FK506,PSL & $40-59$ & + & PSL & 2x Dead \\
\hline Kohler et al. $(2008)^{32}$ & 5 & \begin{tabular}{|l|} 
1x IL2-R \\
Blocker,CSA,AZA,PSL / \\
4x PSL,FK506 \\
\end{tabular} & $20-60$ & + & $\begin{array}{l}\text { ATG, OKT3 / PSL, ATG / } \\
\text { PSL, ATG / PSL }\end{array}$ & $5 x$ Dead \\
\hline Thin et al. $(2008)^{63}$ & 1 & PSL,FK506, AZA & 20 & + & $\begin{array}{l}\text { GM-CSF, PSL, CsA, MMF, } \\
\text { Etanercept }\end{array}$ & Alive \\
\hline Grosskreutz et al. (2008) ${ }^{18}$ & 1 & FK506,PSL & 45 & + & PSL & Alive \\
\hline Lu et al. $(2008)^{35}$ & 1 & Radiosone, PSL, FK506 & 18 & ND & $\begin{array}{l}\text { Stop IS, Thymosin Alpha 1, } \\
\text { ATG, IL-2R Blocker }\end{array}$ & Alive \\
\hline Stotler et al. $(2009)^{58}$ & 1 & - & 20 & + & Alefacept & Alive \\
\hline Piton et al. (2009) $)^{46}$ & 1 & FK506,PSL & 21 & + & PSL,ATG, Infliximab & Alive \\
\hline Gao et al. $(2010)^{16}$ & 1 & FK506 & 9 & ND & decreased FK506 & Alive \\
\hline Chaib et al. $(2011)^{7}$ & 1 & FK506,PSL & 31 & + & ATG, PSL & Dead \\
\hline
\end{tabular}

Legenda: IS: Immunosuupression; CsA: Cyclosporine; AZA: Azathioprin; PSL: Prednisolone; FK506: Tacrolimus; MMF: Mycophenolate Mofetil; RAPA: Rapamycin; IL-2R Blocker, Interleucin-2 Receptor Blocker; ATG: Anti-Thymocyte Globulin; SCT: stem cell transplantation; GM-CSF: Granulocyte Macrophage Colony Stimulating Factor; ND: Not Described. 
The literature describes several approaches used to treat GVHD after LT. These involve the use of available immunossupressive medications and of biological agents aimed at modulating the pathogenic lymphocytes.

Basic immunossupression used in adults and children patients after LT was respectively: FK506 + prednisolone - 49 (50.5\%); cyclosporine + prednisolona + azathioprine - 19 (19,5\%); cyclosporine + prednisolone $-5(5.1 \%)$; others - $23(23.7 \%)$; and cyclosporine + prednisolone $-2(40 \%)$; cyclosporine + prednisolone + azathioprine - 1(20\%); FK506 + prednisolone - $1(20 \%)$; azathioprine + prednisolone $-1(20 \%)$; not mentioned $-1(20 \%)$.

As far as the treatment of GVHD is concern the therapy used in adults and in children patients was respectively: anti-thymocyte globulin + prednisolone - 19 (19.5\%); interleukin-2 receptor blocker - 17 (17.5\%); OKT3 - 12 (12.3\%); cyclosporine - 9 (9.2\%); others - $39(40.2 \%)$ and anti-thymocyte globulin - 1 (20\%); anti-thymocyte globulin + prednisolone -1 (20\%); prednisolone - 1 (20\%); anti-thymocyte globulin + prednisolone + interleukin-2 receptor blocker-1 (20\%); not mentioned -1 .

\section{DISCUSSION}

Acute GVHD after LT was first described by Burdick et al. ${ }^{6}$, occurs when immunocompetent donor lymphocytes originating from the transplanted liver undergo activation and clonal expansion, allowing them to mount a destructive cellular immune response against recipient tissues.

The essential requirements for development of GVHD was described by Billigham as early as $1966^{4}$; first the graft must contain immunologically competent cells; second, the recipient must be recognized as foreign by the graft; and third the recipient must be unable to reject the graft before it mounts an effective immune response.

The aim of therapy for GVHD after LT is to allow the elimination of the unwanted donor lymphocytes by the host immune system. Many drugs and antibodies have been used in the past years such as: corticosteroids (increased or decreased immunossupression); anti-lymphocyte therapy (antithymocyte globulin, antilymphocyte globulin and the monoclonal antilymphocyte agent OKT3); anti-interleukin-2 receptor antibodies (the humanized antibody daclizumab and the murine/human chimeric monoclonal antibody basiliximab) and others like infusion of host immune cells or autologus bone marrow transplant.

The literature describes 28 adult patients treated primarily with corticosteroids and/ or an increased in standard immunosuppressive medications after the diagnosis of GVHD after $\mathrm{LT}^{30,55,56,64}$. Of these patients all were reported to die of complications of GVHD with the exception of one who was reported to be alive only 11 days after therapy was initiated. On the basis of the above results it is evident that treatment of GVHD after LT exclusively with corticosteroids or increase in immunosupression is inadequate longterm therapy.

There have been 37 adult patients reported to have been treated with ATG or OKT3. Of these only $7(18,9 \%)$ patients were reported to be alive at least $>8$ months after $\mathrm{LT}^{2,5,15,21,22,25,27,30,32,35,38,40-42,45-47,49,52,57}$.

Of course this represents an improvement over results that use corticosteroids therapy alone, survival is still poor and the development of a complication of immunosupression such as posttransplantation proliferative disease raises the concern.

There have been 17 adult patients reported to have been treated with anti-interleukin- 2 receptor antibodies Of these only $5(29,4 \%)$ patients were reported to be alive after $\mathrm{LT}^{17,30,35,45,59,63}$. Main complication of using these agents are sepsis, pancytopenia and gastrointestinal bleeding.

Six adult patients have been reported to have been primarily treated for GVHD after LT by a reduction or discontinuation of immunossupression ${ }^{7,47,61}$. Five of these patients were reported to be alive at the time of report with their recovery attributed to reduction in immunosupression. The theoretical benefit of this approach is that by reducing or discontinuing immunosupression, the host immune system may be enabled to rejected the donor lymphocytes mediating the GVHD ${ }^{56}$.

The largest series of GVHD after LT reported in this review was from Smith et al. ${ }^{4}$ and Key et al. ${ }^{30}$ 13 and 7 adults patients respectively. The basic immunossupression after LT was very much the same in the two groups, FK506, azathioprine and prednisolone. The treatment of GVHD was basically increase of prednisolone associated with GM-CSF and interleukin-2 receptor blocker in the former and the latter respectively. All of patients but one ${ }^{56}$ have died after the treatment of this condition for different reasons, demonstrating clearly that there was no standard treatment of acute GVHD so far. The most popular treatment in 96 adults patients were stop immunosupression, prednisolone and anti-thymocyte globulin. Also there is no consensus to date for treating steroidrefractory forms of acute GVHD after LT.

Finally, since TNF-alpha is secreted by monocytes and macrophages leading to donor T-cell activation and inducing a cascade of inflammatory cytokine and cell activation in acute GVHD following LT the use of infliximab (a chimerical mouse/human immunoglobulin $\mathrm{G}$ antibody directed against soluble 
and transmembrane forms of human TNF-alpha) has been successfully reported in treatment of this condition ${ }^{46}$.

In conclusion, although acute GVHD following
$\mathrm{LT}$ is rare complication and mortality is still very high, there is no consensus for the treatment of steroidrefractory forms. Further researches are needed to provide new approach for treating effectively such condition.

\section{REFERENCES}

1. Au WY, Ma SK, Kwong YL, Ng IO, Hawkins BR, Wan TS, Liu CL, Fan ST, Lo CM. Graft-versus-host disease after liver transplantation: documentation by fluorescent in situ hybridisation and human leucocyte antigen typing. Clin Transplant. 2000;14(2):174-7.

2. Aziz $H$, Trigo $P$, Lendoire J, Bianco $G$, Saúl J, Braslavsky G, Kien M, Zylberman M, Cueto G, Imventarza $O$. Successful treatment of graft-vs-host disease after a second liver transplant. Transplant Proc. 1998;30:2891-2.

3. Bhaduri BR, Tan KC, Humphreys S, Williams R, Donaldson P, Vergani D, Mowat AP, Mieli-Vergani G. Graftversushost disease after orthotopic liver transplantation in a child. Transplant Proc. 1990;22:2378-80.

4. Billingham R. The biology of graft-versus-host reactions. Harvey Lect. 1966-1967;62:21-78.

5. Burdick JF, Vogelsang GB, Smith WJ, Farmer ER, Bias WB, Kaufmann SH, Horn J, Colombani PM, Pitt HA, Perler BA. Severe graft-versus-host disease in a livertransplant recipient. N Engl J Med. 1988;318:689-91.

6. Burt M, Jazwinska E, Lynch S, Kerlin P, Gill D, Steadman C, Jonsson J, Strong R, Powell E. Detection of circulating donor deoxyribonucleic acid by microsatellite analysis in a liver transplant recipient. Liver Transpl Surg. 1996;2:391-4.

7. Chaib E, Silva FD, Figueira ERR, Lima FR, Andraus W, D'Albuquerque LA. Graft vs host disease after liver transplantation. Clinics. 2011;66:1-4.

8. Chan EY, Larson AM, Gernsheimer TB, Kowdley KV, Carithers RL Jr, Reyes JD, Perkins JD. Recipient and donors factors influence the incidence of graft vs host disease in liver transplants patients. Liver Transpl. 2007;13:516-22.

9. Cattral MS, Langnas AN, Wisecarver JL, Harper JC, Rubocki RJ, Bynon JS, Fox IJ, Heffron TG, Shaw BW Jr. Survival of graft-versus-host disease in a liver transplant recipient. Transplantation. 1994;57:1271-4.

10. Chinnakotla S, Smith DM, Domiati-Saad R, Agura ED, Watkins DL, Netto G, Uemura T, Sanchez EQ, Levy MF, Klintmalm GB. Acute graft-versus-host disease after liver transplantation: role of withdrawal of immunosuppression in therapeutic management. Liver Transpl. 2007;13:157-61.

11. Cho EH, Suh KS, Yang SH, Lee HW, Cho JY, Cho YB, Yi NJ, Lee KU. Acute graft versus host disease following living donor liver transplantation: first Korean report. Hepatogastroenterology. 2007;54:2120-2.

12. Collins R, Cooper B, Nikaen A, Klintmalm G, Fay JW. Graft versus host disease in a liver transplant recipient. Ann Intern Med. 1992;116:391-2.

13. Comenzo RL, Malachowski ME, Rohrer RJ, Freeman RB, Rabson A, Berkman EM. Anomalous ABO phenotype in a child after an ABO-incompatible liver transplantation. N Engl J Med. 1992;326:867-70.

14. Connors J, Drolet B, Walsh J, Crosby DL, Esterly NB. Morbilliform eruption in a liver transplantation patient. Arch Dermatol. 1996;132:1161-3.

15. De Paoli AM, Bitran J. Graft-versus-host disease and liver transplantation. Ann Intern Med. 1992;117:1701.

16. Gao PJ, Leng XS, Wang D, Li GM, Huang L, Gao J, Zhu JY. Graft vs host disease in liver transplantation: a case report. Front Med China. 2010;4:469-72.

17. Ghali MP, Talwalkar JA, Moore SB, Hogan WJ, Menon $\mathrm{KV}$, Rosen CB. Acute graft-versus-host disease after liver transplantation. Transplantation. 2007;83(3):3656.

18. Grosskreutz C, Gudzowaty $O$, Shi P, Rodriguez-Laiz $\mathrm{G}$, Malone A, Isola L. Partial HLA matching and RH incompatibility resulting in graft versus host reaction and Evans syndrome after liver transplantation. Am J Hematol. 2008; 83:599-601.

19. Guo ZY, He XS, Wu LW, Zhu XF, Ju WQ, Wang DP, You S, Ma Y, Wang GD, Huang JF. Graft-verse-host disease after liver transplantation: a report of two cases and review of literature. World J Gastroenterol. 2008;14:974-9.

20. Hahn AB, Baliga P. Rapid method for the analysis of peripheral chimerism in suspected graft-versus-host disease after liver transplantation. Liver Transpl. 2000;6(2):180-4.

21. Hanaway MJ, Buell JF, Musat Al. Graft-versus-host disease in solid organ transplant. Graft. 2001;4:2056.

22. Hara $\mathrm{H}$, Ohdan $\mathrm{H}$, Tashiro $\mathrm{H}$, Itamoto $\mathrm{T}$, Tanaka $\mathrm{Y}$, Mizunuma K, Tokita D, Onoe T, Ito R, Asahara T. Differential diagnosis between graft-versus-host disease and hemophagocytic syndrome after living-related liver transplantation by mixed lymphocyte reaction assay. J Invest Surg. 2004;17:197-202.

23. Horn TD, Zahurak ML, Atkins D - Lichen planus-like 
histopathologic chatracteristics in the cutaneous graftvs-host reaction. Prognostic significance independent of time course after allogeneic bone marrow transplantation. Arch Dermatol. 1997;133:961-5.

24. Hove WR, van Hoek B, Bajema IM, Ringers J, van Krieken JH, Lagaaij EL. Extensive chimerism in liver transplants: vascular endothelium, bile duct epithelium, and hepatocytes. Liver Transpl. 2003;9(6):552-6.

25. Jamieson NV, Joysey V, Friend PJ, Calne RY. Graftversus-host disease in solid organ transplantation. Transpl Int. 1991;4:67-71.

26. Joseph JM, Mosimann F, Tiercy JM, Roux E, Cerottini JP, Gillet M, Aubert V. PCR confirmation of microchimerism and diagnosis of graft versus host disease after liver transplantation. Transpl Int. 1999;12:468-70.

27. Joysey VC, Wood H, Ramsbottom S, Morgan H, Ford C, Horsford J, Jamieson N, Friend P, Alexander G, Calne RY. Lymphocyte chimaerism after organ transplantation. Transplant Proc. 1992;24:2519-22.

28. Kamei H, Oike F, Fujimoto $Y$, Yamamoto $H$, Tanaka K, Kiuchi T. Fatal graft-versus-host disease after living donor liver transplantation: differential impact of donor-dominant one-way HLA matching. Liver Transpl. 2006;12:140-5.

29. Kashiwagi N, Porter KA, Penn I, Brettschneider L, Starzl TE. Studies of homograft sex and of gamma globulin phenotypes after orthotopic homotransplantation of the human liver. Surg Forum. 1969;20:374-6.

30. Key T, Taylor CJ, Bradley JA, Taylor AL. Recipients who receive a human leukocyte antigen-B compatible cadaveric liver allograft are at high risk of developing acute graft-versus-host disease. Transplantation. 2004;78:1809-11.

31. Kiuchi T, Harada H, Matsukawa H. One-way donorrecipient HLA-matching as a risk factor for graft-versushost disease in living-related liver transplantation. Transpl Int. 1998;11(Suppl 1):383-4.

32. Kohler S, Pascher A, Junge G, Sauer IM, Nagy M, Schönemann C, Koch M, Neumann U, Pratschke J, Neuhaus P. Graft versus host disease after liver transplantation - a single center experience and review of literature. Transplant Intern. 2008;21:441-51.

33. Knox KS, Behnia M, Smith LR, Vance GH, Busk M, Cummings OW, Kwo PY, Wilkes DS. Acute graft-versus-host disease of the lung after liver transplantation. Liver Transpl. 2002;8:968-71.

34. Lehner F, Becker T, Sybrecht L, Lück R, Schwinzer R, Slateva K, Blasczyk R, Hertenstein B, Klempnauer J, Nashan B. Successful outcome of acute graft-versushost disease in a liver allograft recipient by withdrawal of immunosuppression. Transplantation. 2002;73:307-10.

35. Lu Y, Wu LQ, Zhang BY, Cao JY. Graft-versus-host disease after liver transplantation: successful treatment of a case. Transplant Proc. 2008;40:3784-6.
36. Marubayashi S, Matsuzaka C, Takeda A, Costa MM, Jamieson NV, Joysey V, Calne RY. Fatal generalized acute graft-versus-host disease in a liver transplant recipient. Transplantation. 1990;50:709-11.

37. Mazzaferro V, Andreola S, Regalia E Poli F, Doci R, Bozzetti F, Gennari L. Confirmation of graft-versus-host disease after liver transplantation by PCR HLA-typing. Transplantation. 1993;55:423-5.

38. Merhav HJ, Landau M, Gat A, Baratz M, Bialy-Golan A, Konikof F, Bril S, Nakache R. Graft versus host disease in a liver transplant patient with hepatitis $B$ and hepatocellular carcinoma. Transplant Proc. 1999;31:1890-1.

39. Merle C, Blanc D, Flesch M, Carbillet JP, Miguet JP, Gillet M. A picture of epidermal necrolysis after hepatic allograft. Etiologic aspects. Ann Dermatol Venereol. 1990;117:635-9.

40. Neumann UP, Kaisers U, Langrehr JM, Müller AR, Blumhardt $G$, Bechstein WO, Lobeck H, Riess $H$, Zimmermann R, Neuhaus P. Fatal graft-versus-hostdisease: a grave complication after orthotopic liver transplantation. Transplant Proc. 1994;26:3616-7.

41. Paizis G, Tait BD, Kyle P, Angus PW, Grigg AP. Successful resolution of severe graft versus host disease after liver transplantation correlating with disappearance of donor DNA from the peripheral blood. Aust N Z J Med. 1998;28:830-2.

42. Pageaux GP, Perrigault PF, Fabre JM, Portales $P$, Souche B, Dereure O, Eliaou JF, Larrey D, Domergue $\mathrm{J}$, Michel $\mathrm{H}$. Lethal acute graft-versus-host disease in a liver transplant recipient: relations with cell migration and chimerism. Clin Transplant. 1995;9:65-9.

43. Patriarca F, Sperotto A, Damiani D, Morreale G, Bonifazi F, Olivieri A, Ciceri F, Milone G, Cesaro S, Bandini G, Dini G, Corradini P, Fanin R. Infliximab treatment for steroid-refractory acute graft VS host disease. Haematologica. 2004;89:1352-9.

44. Peck Peck GL, Elias PM, Graw Rg Jr. Graft-versushost reaction and toxic epidermal necrolysis. Lancet. 1972;ii:1151-3.

45. Perri R, Assi M, Talwalkar J, Heimbach J, Hogan W, Moore SB, Rosen CB. Graft vs. host disease after liver transplantation: a new approach is needed. Liver Transplant. 2007;13:1092-9.

46. Piton G, Larosa F, Minello A, Becker MC, Mantion G, Aubin F, Deconinck E, Hillon P, Di Martino V. Infliximab treatment for steroid-refractory acute graft-versus-host disease after orthotopic liver transplantation: a case report. Liver Transpl. 2009;15(7):682-5.

47. Pollack MS, Speeg KV, Callander NS, Freytes CO, Espinoza AA, Esterl RM, Abrahamian GA, Washburn WK, Halff GA. Severe, late-onset graft-versus-host disease in a liver transplant recipient documented by chimerism analysis. Human Immunol. 2005; 66: 2831.

48. Provenzale JM, Graham ML. Reversible leukoenceph- 
alopathy associated with graft-versus-host disease: MR findings. Am J Neuro Rad 1995; 17: 1290-1293.

49. Redondo P, Espana A, Herrero JI, Quiroga J, Cienfuegos JA, Azanza JR, Prieto J. Graft-versus-host disease after liver transplantation. J Am Acad Dermatol 1993; 29: 314-317.

50. Romagnuolo J, Jewell LD, Kneteman NM, Bain VG. Graft-versus-host disease after liver transplantation complicated by systemic aspergillosis with pancarditis. Can J Gastroenterol. 2000;14:637-40.

51. Rosen GB, Ng CS, Moore SB. Clinical and pathological features of graft-versus-host disease after liver transplantation: a case report and review of the literature. Clin Transplant. 1993;7:52-5.

52. Sanchez-Izquierdo JA, Lumbreras C, Colina F, Martinez-Laso J, Jiménez C, Gómez R, García I, Alvarez M, Arnaiz-Villena A, Moreno E. Severe graft versus host disease following liver transplantation confirmed by PCR-HLA-B sequencing: report of a case and literature review. Hepatogastroenterology. 1996;43:1057-61.

53. Starzl TE, Demetris AJ, Trucco M, Ramos H, Zeevi A, Rudert WA, Kocova M, Ricordi C, Ildstad S, Murase N. Systemic chimerism in human female recipients of male livers. Lancet. 1992;340(8824):876-7.

54. Schäppi MG, Belli DC, Rimensberger PC, Chardot C, Kaya G, Tiercy JM, Ozsahin H. Fatal GvHD as a complication of liver transplantation for undetermined fulminant hepatic failure and associated aplastic anemia. Liver Transpl. 2006;12(11):1693-7.

55. Schmuth M, Vogel W, Weinlich G, Margreiter R, Fritsch $P$, Sepp N. Cutaneous lesions as the presenting sign of acute graft-versus-host disease following liver transplantation. Br J Dermatol. 1999;141(5):901-4.

56. Smith DM, Agura E, Netto G, Collins R, Levy M, Goldstein R, Christensen L, Baker J, Altrabulsi B, Osowski L, McCormack J, Fichtel L, Dawson DB, Domiati-Saad R, Stone M, Klintmalm G. Liver transplantassociated graft-versus-host disease. Transplantation. 2003;75:118-26.

57. Soejima Y, Shimada M, Suehiro T, Hiroshige S, Gondo H, Takami A, Yasue S, Maehara Y. Graft-versus-host disease following living donor liver transplantation. Liver Transpl. 2004;10:460-4.

58. Stotler CJ, Eghtesad B, Hsi E, Silver B. Rapid resolution of GVHD after orthotopic liver transplantation in a patient treated with alefacept. Blood. 2009;113:5365-6.
59. Sudhindran S, Taylor A, Delriviere L, Collins VP, Liu L, Taylor CJ, Alexander GJ, Gimson AE, Jamieson NV, Watson CJ, Gibbs P. Treatment of graft-versushost disease after liver transplantation with basiliximab followed by bowel resection. Am J Transplant. 2003;3(8):1024-9.

60. Sun B, Zhao C, Xia Y, Li G, Cheng F, Li J, Zhang F, Wang $X$. Late onset of severe graft-versus-host disease following liver transplantation. Transpl Immunol. 2006;16: 250-3.

61. Taylor AL, Gibbs P, Bradley A. Acute graft versus host disease following liver transplantation: the enemy within. Am J Transplant. 2004;4:466-74.

62. Taylor AL, Gibbs P, Sudhindran S Key T, Goodman $\mathrm{RS}$, Morgan $\mathrm{CH}$, Watson CJ, Delriviere L, Alexander GJ, Jamieson NV, Bradley JA, Taylor CJ. Monitoring systemic donor lymphocyte macrochimerism to aid the diagnosis of graft-versus-host disease after liver transplantation. Transplantation. 2004;77:441-6.

63. Thin L, Macquillan G, Adams L, Garas G, Seow C, Cannell P, Augustson B, Mitchell A, Delriveire L, Jeffrey G. Acute graft-versus-host disease after liver transplant: novel use of etanercept and the role of tumor necrosis factor alpha inhibitors. Liver Transpl. 2009;15:421-6.

64. Roberts JP, Ascher NL, Lake J, Capper J, Purohit S, Garovoy M, Lynch R, Ferrell L, Wright T. Graft vs. host disease after liver transplantation in humans: a report of four cases. Hepatology. 1991;14:274-81.

65. Volc Platzer B, Rappersberger K, Mosberger I - Sequential immunohistologic analysis of the skin following allogeneic bone marrow transplantation. J Invest Dematol. 1988;91:162-8.

66. Walling HW, Voigt MD, Stone MS. Lichenoid Graft vs. Host disease following liver transplantation. J Cutan Pathol. 2004;31:179-84

67. Wang B, Lu Y, Yu L, Liu C, Wu Z, Liu X, et al. Diagnosis and treatment for graft-versus-host disease after liver transplantation: two case reports. Transplant Proc. 2007;39(5):1696-8.

68. Whitington PF, Rubin CM, Alonso EM, McKeithan TW, Anastasi J, Hart J, Thistlethwaite JR. Complete lymphoid chimerism and chronic graft-versus-host disease in an infant recipient of a hepatic allograft from an HLAhomozygous parental living donor. Transplantation. 1996;62:1516-9. 